"compensated for temperature," were in use when Mr. Fischer was first engaged on the Coast and Geodetic Survey. These gave place to 5-metre contact rods, consisting of a single bar of steel enclosed in a closely fitting wooden case, and covered with padded canvas. For use in the field they were mounted on tripods and placed end to end. In the hands of skilled observers it was possible with this type of bar to attain a degree of accuracy approaching $I$ part in $2,000,000$. In the elaborate apparatus devised by Dr. R. S. Woodward a line bar was supported when in use on a steel trough and covered with crushed ice, the trough being carried by two trucks travelling on a portable track. Micrometer-microscopes were mounted on supports fixed in the ground at carefully measured intervals approximately equal to the length of the bar. The operation of measuring was effected by bringing the bar under the first two microscopes and then setting the cross-wires of the micrometers on the lines of the bar; then without disturbing the reading of the forward micrometer the bar was displaced longitudinally until the line at its rear end was brought under the fo ward microscope, while at the same time an obser er at the forward end set the micrometer on the line at that end, this process being repeated throughout the length of the base line. A kilometre base measured in this manner was estimated to have an accuracy of $x$ part in $3,000,000$.

Eimbeck's duplex base bars were next employed on the survey. These consisted of two concentric brass tubes in the inner of which a brass and a steel measuring bar were mounted. The inner tube could be rotated through $180^{\circ}$ so as to equalise the temperature of the brass and steel components if one side of the apparatus should be more exposed to direct radiation. This method was in its turn superseded by the introduction of invar tapes. All primary bases of the United States Survey are now measured with invar tapes, tested preliminarily at the Bureau of Standards, and by this means base operations, while maintaining the high degree of precision which the work demands, admit of vastly greater rapidity in the field, with a consequent reduction in the expense involved.

\section{PLIOCENE MAN.}

THE discussion originated by the Rev. Osmund Fisher in NATuRE of September 4, 19I3 (vol. xcii., p. 6), has led to the systematic exploration, by a committee of the Dorset Field Club, of the Dewlish "elephant-trench," and the report on the excavations was read at the anniversary meeting on May 4.

This curious trench in the chalk yields bones of the Pliocene Elephas meridionalis, and $\mathrm{Mr}$. Fisher suggested that it was artificial and dug for trapping the elephants. There can no longer be any doubt that the french was of natural origin. The elaborate plans, elevations, and photographs exhibited by Mr. Charles Prideaux, who superintended the excavations, show clearly that a few feet below the surface the supposed trench divides into a chain of pipes or potholes in the chalk connected by a narrow joint. These become very narrow below; but one of them was traced to a depth of $36 \mathrm{ft}$. One or two of the smaller pipes still show traces of the lining of black clay commonly found in pipes caused by solution in the chalk; the larger ones were. filled with chalky sand full of flints, and Tertiary material; many of the flints were beautifully polished. Flakes caused by sudden changes of temperature were also abundant.

Mr. Clement Reid discussed the geological evidence. He thought that it proved the existence of a fissure or joint transverse to the valley of the Devil's Brook. Along this joint a chain of pipes was formed by the

$$
\text { No. } 2376 \text {, voL. 95] }
$$

action of percolating rain-water. Then the pipes nearest to the valley-bottom acted as "swallow-holes," into which the brook sank, the constant swirl of the water laden with calcareous sand giving the flints the wonderful polish now seen. In short, the Devil's Brook, then flowing at a level $90 \mathrm{ft}$. higher, was a "winter bourne," which at Dewlish, for part of the year, at any rate, was swallowed up and disappeared into these pot-holes. Such pot-holes are common in the Carboniferous Limestone, though rare in the Chalk. This chain of pot-holes acted as a natural pitfall, into which the elephants fell, or into which their bones were washed; thus far Osmund Fisher was right in calling it an "elephant-trap," though it probably had a natural origin. Mr. Reid saw no sign of human agency in the trench. The date of the deposit must still remain somewhat uncertain, for all the determinable bones belong: to $E$. meridionalis; and this species, though mainly Pliocene, may have lived on into early Pleistocene times.

Mr. Reid Moir, in another report, described a number of the flints as showing undoubted human workmanship of eolithic type. Mr. Reginald Smith, however, after an examination of the same specimens, thinks that one or two of them may possibly be worked, the others he rejects.

A report by $\mathrm{Mr}$. Dewey pointed out that a sample of calcareous sand from the trench proved under the microscope to consist mainly of minute rhombs of calcite, such as would be precipitated from a saturated solution. This he thought pointed to an arid climate.

\section{SYSTEMATIC ZOOLOGY OF THE INVERTEBRATA.}

$A M O N G$ recent systematic papers on the invertebrates, a noteworthy account of the parasitic worms collected on the British Antarctic (Terra Nova) Expedition, written by Dr. R. T. Leiper and Dr. E. L. Atkinson, has been published by the British Museum ("Terra Nova Zoologv." vol. ii., No. 3). From the summary of results we learn that the Ross Expedition of $184 I^{-4}$ brought back two species of Entozoa; the Scott (Discovery) Expedition of I90I-4 four species; the Bruce (Scotia) Expedition seventeen species; the French (Pourquoi Pas?) Expedition eighteen species; the Terra Nova twenty-eight species. These figures show how greatly zoological knowledge has been increased through our latest national Antarctic enterprise. Three of the worms now recorded from the far south had previously been known only from the Arctic regions. Two of these-a. Filaria and an Echinorrhynchus-have whales as their hosts in both localities, but the third-a monostomid trematode, Ogmogaster plicatum, Creplin-is parasitic in rorquals in the north, and in the Crab-eating and Weddell's Seals in the south; a remarkable divergence in habit.

From home waters there is still much material to be gathered, and C. M. Selbie's important paper on the Decapoda Reptantia of the coasts of Ireland, part i (Fisheries, Ireland, Sci. Invest., I9I4, i.), adds to the fauna of the Britannic marine area the family Eryonidæ, as represented by four species of Polycheles and four of Eryonicus. These were all taken in deep water off the west coast of Ireland, though the specimens of Eryonicus "lead a free-swimming life at a considerable distance from the bottom." The paper is illustrated by fifteen excellently drawn plates.

A very important paper on those interesting copepod fish-parasites, the Lernæopodidæ, has been published by C. B. Wilson in the Proc. U.S. Nat. Museum (vol. xlvii., pp. $\left.56_{5} \rightarrow 29\right)$. Though dealing especially ; with species from North American waters, the author gives a revision of the whole family, thus affording a trust- 